\title{
1,3-Dipolar cycloadditions of acridine with nitrile oxides
}

\author{
Antonino Corsaro, ${ }^{* a}$ Venerando Pistarà, ${ }^{a}$ Antonio Rescifina, ${ }^{a}$ Giovanni Romeo, ${ }^{\mathrm{b}}$ Roberto \\ Romeo, ${ }^{\mathrm{b}}$ and Ugo Chiacchio ${ }^{* \mathrm{a}}$ \\ ${ }^{[a]}$ Dipartimento di Scienze Chimiche, Università di Catania, viale A. Doria 6, I-95125 Catania, \\ Italy ${ }^{[b]}$ Dipartimento Farmaco-Chimico, Università di Messina, viale SS. Annunziata, I-98168 \\ Messina, Italy \\ E-mail: uchiacchio@dipchi.unict.it; acorsaro@dipchi.unict.it
}

\section{Dedicated to Professor Albert Padwa on the occasion of his $65^{\text {th }}$ birthday}

(received 27 Mar 02; accepted 24 May 02; published on the web 01 Jun 02)

\begin{abstract}
Site- and regio-isomeric mono-cycloadducts 9 are formed in the reactions of mesito- $1 \mathrm{~b}$ and dichloromesitonitrile oxide $1 \mathrm{c}$ with acridine 6 in a 1:2 ratio, while the reaction of $1 \mathrm{~b}$ and 6 in a 10:1 ratio afforded, besides the mono-cycloadduct $9 \mathrm{~b}$ and traces of the corresponding oxime 10b, the bis-cycloadduct 12 with the opposite regiochemistry to that of the mono-cycloadducts 9 and the adduct 13 .
\end{abstract}

Keywords: 1,3-Dipolar cycloadditions, nitrile oxide, acridine

\section{Introduction}

Intermolecular reactions of heteroaromatics with 1,3-dipoles have provided an interesting way for the synthesis of complex heterocyclic systems, with high levels of regio- and stereochemical control. Previously, one of us found that pyridine, in apolar solvents, adds to benzonitrile oxide 1a to give two bis-cycloadducts ${ }^{1} 4(26 \%)$ and $5(9 \%)$, which arise from the addition of a second molecule of 1,3-dipole to the highly reactive dienamine moiety of the initial mono-cycloadduct 3 (Scheme 1). The formation of $\mathbf{3}$ has been rationalised in terms of a pseudo-pericyclic ${ }^{2}$ process involving the formation of an initial zwitterion 2, originating from the attack of the heterocyclic nitrogen atom on the dipole carbon, which undergoes a subsequent electrocyclic closure to the corresponding mono-cycloadduct $\mathbf{3}$. 


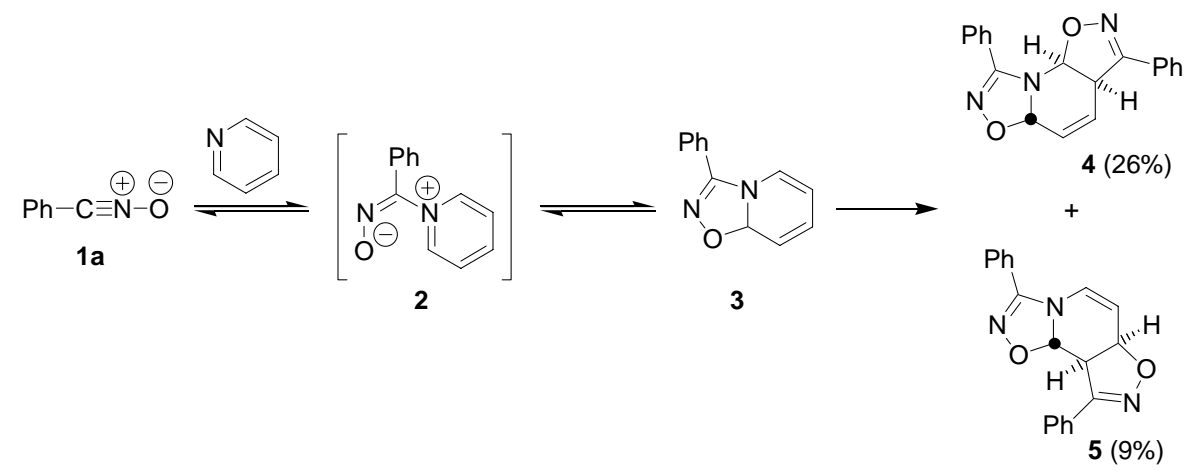

\section{Scheme 1}

In a search for direct evidence of the proposed intermediates, we explored the possibility of increasing their stability by appropriate modifications of the reactants. After having trapped the mono-cycloadduct 3 by exposing pyridine to two different nitrile oxides, ${ }^{3}$ we have succeeded in stabilizing the zwitterion 2 with respect to the reactants by providing a delocalization of negative charge $^{4}$ or by reducing the loss of aromaticity involved in the cycloaddition process. ${ }^{1,5}$

As an extension of this research, we now report our investigation of the reactivity of acridine $\mathbf{6}$ towards benzo- 1a, mesito- 1b, and dichloromesito-nitrile 1c oxides. Two reaction pathways have been observed: the first one is related to the nucleophilicity of the acridine nitrogen atom and then to the possible isolation of a zwitterion 7, whose stability should be improved by delocalization of the positive charge on the three aromatic rings. The acridine nitrogen atom, even if less nucleophilic than that of pyridine or quinoline, ${ }^{6}$ appears to be associated to a good value of electron density ${ }^{7}$ and then to a good nucleophilicity, as is supported by the large number of acridinium salts prepared by alkylation, which is favoured by the use of polar solvents. ${ }^{8}$

The second mode of reactivity of acridine is the dipolarophilic activity of the diene system included in its benzenoid structure. Because the nitrogen atom in acridine does not keep an external position, its cyclohexadiene ring could add to nitrile oxides, as does anthracene, ${ }^{9}$ to give site- and regio-isomeric mono-cycloadducts; this latter aspect arises from our recent studies on polycyclic aromatic hydrocarbons (PAHs) ${ }^{9-11}$ and aza-analogues of phenanthrene. ${ }^{12}$

Acridine participates in many nucleophilic addition reactions, which lead to acridan products through nucleophilic attack at the C-9 carbon followed, in many instances, by an oxidation process. ${ }^{6}$ The predicted position of electrophilic attack is, on the contrary, at the C-4 position and is in agreement with the experimentally observed products. ${ }^{13}$ To the best of our knowledge, however, there are no literature reports concerning cycloaddition reactions of acridine where this acts as a $2 \tilde{\pi}$ component. 


\section{Results and Discussion}

Reactions between acridine $\mathbf{6}$ and the nitrile oxides 1a-c were initially carried out by adding portionwise one equivalent of the nitrile oxide to a solution containing two equivalents of 6 in dry diethyl ether at $0{ }^{\circ} \mathrm{C}$; after three hours, the reaction mixture was left to reach room temperature and to react until the 1,3-dipole was consumed. Under these conditions, no zwitterion 7 was obtained, but its initial formation can be deduced by the isolation of the dioxadiazine dimer $\mathbf{8}$ in $38.2 \%$ yields from $\mathbf{1 a}$ and $\mathbf{6}$ pre-formed in a neutral solution at $0{ }^{\circ} \mathrm{C}$, in dimethylformamide. ${ }^{14}$ The production of $\mathbf{8}$ falls to $0.5 \%$ in the absence of acridine, in agreement with a literature report, ${ }^{15}$ which attributes the abnormal dimerization of $\mathbf{1 a}$ to the dioxadiazine $\mathbf{8}$ to the initial formation of a zwitterion (Scheme 2).

In contrast, when reactions of $\mathbf{6}$ with 1a-c were carried out in refluxing dry toluene for two days, they provided the mono-cycloadducts $9 \mathrm{~b}$ and $9 \mathrm{c}$, in $12 \%$ and $14 \%$ yield, respectively, but not 9a (Scheme 2). No traces of other regio- and site-isomers were detected by ${ }^{1} \mathrm{H}-\mathrm{NMR}$ analysis of the crude reaction mixtures.

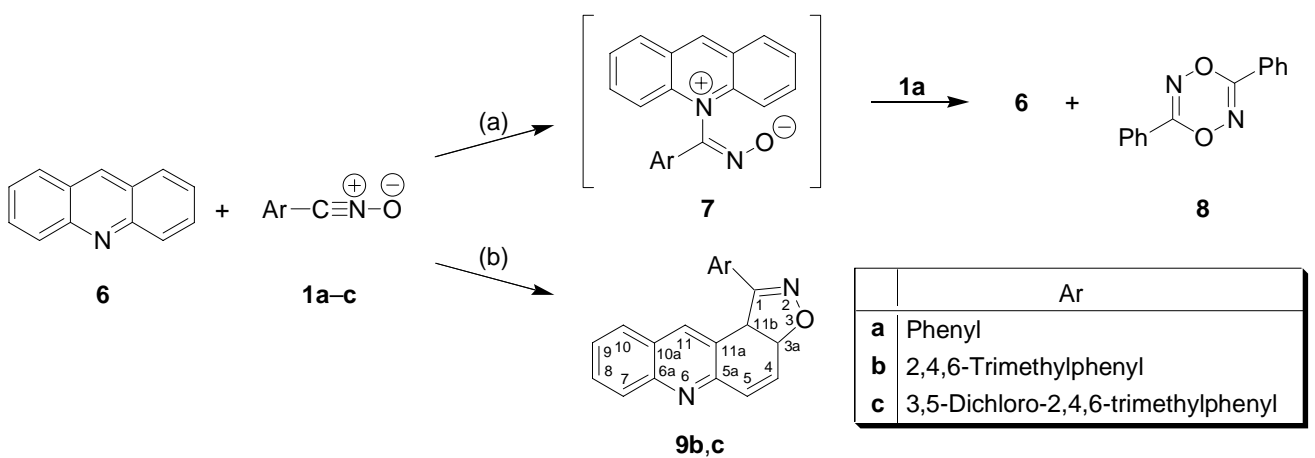

Scheme 2. (a) $N, N$-Dimethylformamide, $0{ }^{\circ} \mathrm{C}$; (b) toluene, reflux.

The structures of the dihydroisoxazolo-[4,5-a]-acridines $9 \mathbf{b}$ and $9 \mathbf{c}$ were assigned on the basis of ${ }^{1} \mathrm{H}$ - and ${ }^{13} \mathrm{C}$-NMR spectra and confirmed through NOEDS experiments. In particular, for the regioisomer $9 \mathbf{b}$, diagnostic resonances for $\mathrm{H}-11 \mathrm{~b}$ and $\mathrm{H}-3 \mathrm{a}$ appear at $\delta 4.98$ as a doublet, and at $5.86 \mathrm{ppm}$ as a double doublet of doublets, respectively; the $\mathrm{H}-4$ and $\mathrm{H}-5$ olefinic protons resonate as double doublets at $6.44(J=2.9$ and $10.2 \mathrm{~Hz})$ and $7.00(J=1.4$ and $10.2 \mathrm{~Hz}) \mathrm{ppm}$, respectively. Irradiation of the $\mathrm{H}-11$ proton, gives rise to positive NOE enhancements for $\mathrm{H}-11 \mathrm{~b}$ (7.6\%), H-10 (8.8\%), and the methyl protons of the mesityl moiety at C-1 (1.4\%). Moreover, by irradiating $\mathrm{H}-11 \mathrm{~b}$, NOE effects were observed for the methyl protons (6.2\%), H-3a (11.9\%), and $\mathrm{H}-11(8.2 \%)$; in turn the irradiation of $\mathrm{H}-3 \mathrm{a}$ shows NOE effects for $\mathrm{H}-11 \mathrm{~b}(9.0 \%)$ and $\mathrm{H}-4$ (6.2\%). The ${ }^{13} \mathrm{C}-\mathrm{NMR}$ spectrum reveals signals for $\mathrm{C}-11 \mathrm{~b}, \mathrm{C}-3 \mathrm{a}$ and $\mathrm{C}-1$ of the dihydroisoxazole ring at 52.12, 76.72 and $159.20 \mathrm{ppm}$, respectively. 
Further confirmation of the assigned structures was obtained by cleavage of the C-O bond of the dihydroisoxazole ring upon treatment with sodium ethoxide in ethanol, which afford the corresponding oximes 10b,c (Scheme 3). ${ }^{16,17}$

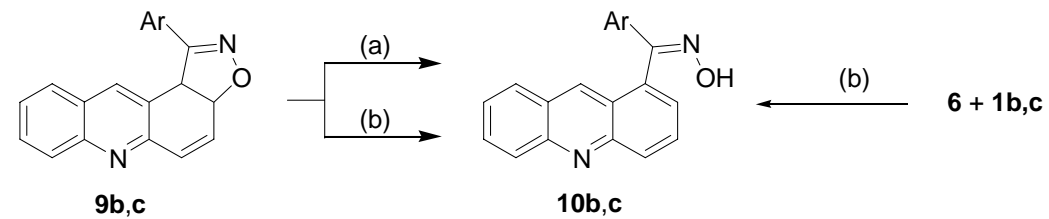

Scheme 3. (a) EtONa, EtOH, then $\mathrm{HCl}$; (b) microwave or $\Delta$.

The oximes 10b,c were resistant to acidic or basic hydrolysis and did not afford the corresponding ketones. Their structures were derived from the following spectroscopic observations. Compared to the compounds 9, the ${ }^{1} \mathrm{H}-\mathrm{NMR}$ spectra of $\mathbf{1 0 b}, \mathbf{c}$ show the lack of the $\mathrm{H}-11 \mathrm{~b}$ and $\mathrm{H}-3 \mathrm{a}$ resonances and the appearance of the oxime proton in the range 10-11 ppm, exchangeable with deuterium oxide. In the ${ }^{13} \mathrm{C}$ - NMR spectra, the oxime carbon resonates at $160.82 \mathrm{ppm}$.

The oximes 10b,c were also isolated as exclusive products when the reactions between $\mathbf{6}$ and $\mathbf{1 b}, \mathbf{c}$ in the previously used stoichiometric ratio, were performed directly in a simple domestic microwave oven under irradiation $(600 \mathrm{~W})$ for $60 \mathrm{sec}$; analogous results were also obtained when the reactions were conducted in the absence of solvent, in an oil bath preheated at $180^{\circ} \mathrm{C}$, for 60 sec (Scheme 3).

These data and the obtention of $\mathbf{1 0 b}$ from $9 \mathrm{~b}$ by heating at $180^{\circ} \mathrm{C}$ for $60 \mathrm{sec}$ in the absence of solvent, indicate that the first step of the reaction is the cycloaddition leading to $\mathbf{9 b}, \mathbf{c}$ : then the reorganisation of the dihydroisoxazole rings of $\mathbf{9 b}, \mathbf{c}$ into the corresponding oxime 10b,c takes place owing to a thermal effect rather than by an irradiating effect by microwaves.

The mono-cycloadduct $\mathbf{9 b}$ was also subjected to chemical reduction with lithium aluminium hydride $\left(\mathrm{LiAlH}_{4}\right)$, and by catalytic hydrogenation with Raney $\mathrm{Ni}$ or $\mathrm{Pd}-\mathrm{C}$. In analogy with the behaviour observed for mono-cycloadducts of $\mathrm{PAHs}^{9-11}$ and aza-analogues of phenanthrene, ${ }^{12}$ treatment of $\mathbf{9 b}$ with $\mathrm{LiAlH}_{4}$ at room temperature in tetrahydrofuran for 3 hours affords the oxime 10b, according to a reaction pathway where $\mathrm{LiAlH}_{4}$ acts as a base rather than a reducing agent. $^{17}$

The catalytic reduction with Raney Nickel $\left(\mathrm{H}_{2}, 20\right.$ psi) afforded a complex and nonanalysable mixture. However, the hydrogenation with $\mathrm{Pd}-\mathrm{C}\left(\mathrm{H}_{2}, 60 \mathrm{psi}\right)$ in methanol for $6 \mathrm{~h}$ afforded mainly the reduction product 11, whose structure was assigned on the basis of analytical and spectroscopic data (Scheme 4). In particular, the ${ }^{1} \mathrm{H}-\mathrm{NMR}$ spectrum contains, besides signals characteristic of the dihydro-isoxazole ring, a multiplet centred at $1.68 \mathrm{ppm}$ for the 5-methylene protons and two multiplets at 2.00 and $2.64 \mathrm{ppm}$ for the two protons of the 4-methylene group. The ${ }^{13} \mathrm{C}$-NMR spectrum shows resonances for aromatic carbons, diagnostic signals of the 
dihydroisoxazole carbons at 53.99 and 77.00 ppm, and signals at 22.54 and 26.92 of C-4 and C5 , respectively.

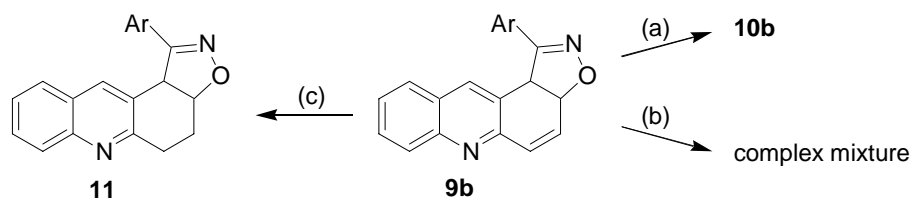

Scheme 4. (a) $\mathrm{LiAlH}_{4}$; (b) $\mathrm{H}_{2}$, Raney Ni; (c) $\mathrm{H}_{2}, \mathrm{Pd} / \mathrm{C}$.

In order to examine the site-, regio-, and stereo-selectivity of the eventual bis-cycloaddition products, the reaction of $\mathbf{6}$ and $\mathbf{1 b}$ in a 1:10 ratio was performed in refluxing toluene. Besides the mono-cycloadduct 9b (25\%) and traces of the oxime 10b, two new products, 3,6-di-(2,4,6trimethylphenyl)-3a,12b-dihydroisoxazolo[5,4-a: 5',4'-c]acridine (12) (8\%) and 5-acridin-1-yl3,5-di-(2,4,6-trimethyl-phenyl)-1,2,4-oxadiazol-4(H)-ol (13) (7\%), were obtained. Their structures were assigned on the basis of ${ }^{1} \mathrm{H}$ - and ${ }^{13} \mathrm{C}-\mathrm{NMR}$ spectra and confirmed by NOEDS experiments (Scheme 5).

Thus, the ${ }^{1} \mathrm{H}-\mathrm{NMR}$ spectrum of $\mathbf{1 2}$ shows distinct resonances for the methyl groups and aromatic protons of the two mesityl substituents (see Experimental), two doublets at 5.19 and $6.29 \mathrm{ppm}$ for the dihydroisoxazole protons, and five signals for acridine protons. The assignments were made on the basis of NOEDS experiments. Thus, the irradiation of $\mathrm{H}-12 \mathrm{~b}$ results in enhancements of the $\mathrm{H}-3 \mathrm{a}$ and $\mathrm{H}-12$ resonances; in turn, positive NOE effects have been measured for $\mathrm{H}-12 \mathrm{~b}$ and the methyl protons centred at $2.08 \mathrm{ppm}$, upon irradiation of the

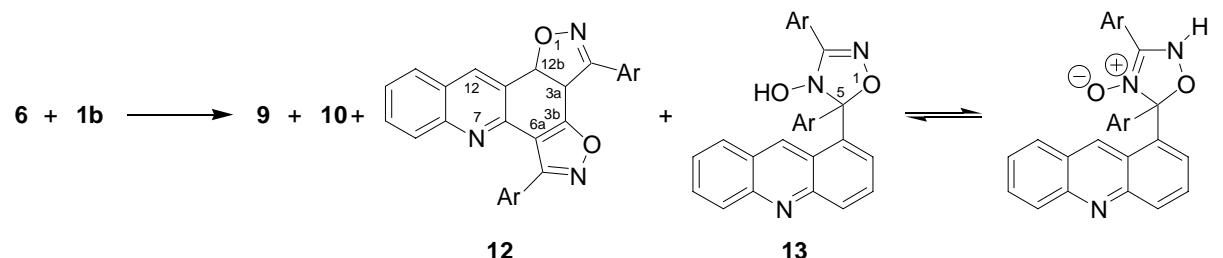

\section{Scheme 5}

$\mathrm{H}-3$ a proton. Conversely, irradiation of the methyl protons at $2.18 \mathrm{ppm}$ causes a very weak enhancement of the H-8 proton. The ${ }^{13} \mathrm{C}-\mathrm{NMR}$ spectrum was characterised by four signals in the range 19.6-21.2 ppm for methyl carbons, three signals for C-3a, C-12b and C-3 of the dihydroisoxazole ring at 48.9, 81.4 and $158.4 \mathrm{ppm}$, and three signals at 114.3, 148.1 and 164.5 ppm for the isoxazole $\mathrm{C}-6 \mathrm{a}, \mathrm{C}-3 \mathrm{~b}$ and $\mathrm{C}-6$, respectively. Besides the resonances of methyl protons in the range $2.26-2.44 \mathrm{ppm}$ and mesityl protons at 6.88 and $6.93 \mathrm{ppm}$, the ${ }^{1} \mathrm{H}-\mathrm{NMR}$ spectrum of 13 shows two doublets, a double triplet, a singlet and three multiplets for H-2-H-9 protons, in the range $7.52-8.05 \mathrm{ppm}$ and a very broad singlet at $6.92 \mathrm{ppm}$ for the $N$-hydroxyl proton. ${ }^{18}$ The ${ }^{13} \mathrm{C}-\mathrm{NMR}$ spectrum shows diagnostic signals for C-3 and C-5 at 160.75 and 115.21 
ppm, and the IR spectrum shows a broad absorption band at $3352 \mathrm{~cm}^{-1}$ for $\mathrm{OH}$ or $\mathrm{NH}$ stretching. ${ }^{19}$

While the dihydro-oxadiazole derivative $\mathbf{1 3}$ was an expected compound, since $\mathbf{6}$ is a very poor dipolarophile and then a second molecule of nitrile oxide preferentially adds to the $\mathrm{C}=\mathrm{N}$ double bond of an initially formed adduct $9 \mathbf{b},{ }^{20}$ formation of the bis-cycloadduct 12 cannot be rationalised directly on the basis of the isolated mono-cycloadduct. Tentatively, we assume that this compound could originate from the other, unisolated regioisomer $\mathbf{1 4 b}$, which regioselectively undergoes addition of a second molecule of $\mathbf{1 b}$ to the C-4-C-5 double bond, followed by the loss of a hydrogen molecule (Scheme 6).

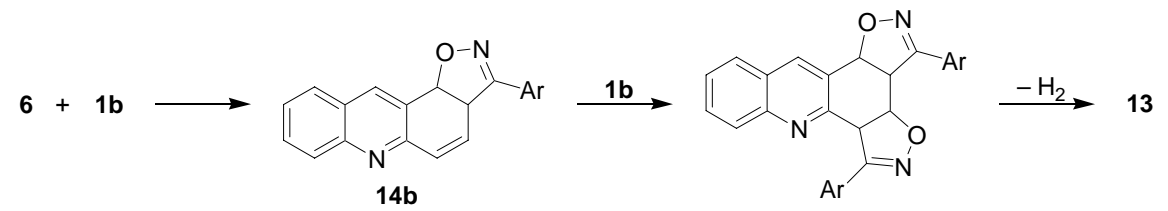

\section{Scheme 6}

In conclusion, contrary to expectation of its inertia, mainly owing to loss of its aromaticity, and high nitrogen- nucleophilicity, 6 reacts as a $2 \tilde{\pi}$ component towards nitrile oxides affording the mono-cycloadducts 9 in low yields, as do PAHs ${ }^{9-11}$ and aza-analogues of phenanthrene. ${ }^{12}$ The reaction performed with 10 equiv. of the 1,3-dipole, led to two new products, 12 and $\mathbf{1 3}$, as well as the mono-cycloadduct $\mathbf{9 b}$ and traces of the oxime 10b. Moreover, semi-empirical calculations at the PM3 level, performed in order to rationalise the observed experimental results, are not completely in accord with the FMO theory: although the site- selectivity of the reactions is predicted correctly, the observed regioselectivity of mono-cycloadducts is inverted. An $a b$ initio study is in progress, and will be reported in due course.

\section{Experimental Section}

General Procedures. Melting points were determined with a Kofler apparatus and are uncorrected. Elemental analyses were performed with a Perkin-Elmer elemental analyzer. IR spectra were recorded on a Perkin-Elmer Paragon 500 FT-IR Spectrometer using potassium bromide discs. NMR spectra were recorded on a Varian instrument at 200 or $500 \mathrm{MHz}\left({ }^{1} \mathrm{H}\right)$ and at 50 or $125 \mathrm{MHz}\left({ }^{13} \mathrm{C}\right)$ using deuteriochloroform or dimethyl sulfoxide- $\mathrm{d}_{6}$ as solvent; chemical shifts are given in ppm $(\delta)$ from TMS as internal standard. Thin-layer chromatographic separations were performed on Merck silica gel $60-\mathrm{F}_{254}$ precoated aluminium plates. Preparative separations were by column- and flash chromatography using Merck silica gel 0.063-0.200 mm and $0.035-0.070 \mathrm{~mm}$, respectively, with cyclohexane-ethyl acetate mixtures as eluent. Microwave irradiations were performed with a Moulinex FM 5745 A domestic oven at 600W. 
The identification of samples from different experiments was secured by mixed mps and superimposable IR spectra.

Starting materials. Benzonitrile oxide was prepared in the appropriate solvent from benzhydroximic acid chloride ${ }^{21}$ and $14 \%$ aqueous sodium hydroxide according to a known procedure. ${ }^{14}$ Mesitonitrile oxide ${ }^{22}$ and 3,5-dichloro-2,4,6-trimethylbenzonitrile oxide ${ }^{23}$ were prepared by literature methods. Benzaldoxime, mesitoxime and acridine were purchased from Aldrich Co. All solvents were dried according to literature methods. ${ }^{24}$

\section{Cycloaddition reactions of 6 with $1 \mathrm{a}-\mathrm{c}$ in $2: 1$ ratio}

At room temperature. To a solution of $6(8 \mathrm{mmol})$ in dry diethyl ether $(10 \mathrm{~mL})$, the 1,3-dipoles 1a-c $(4 \mathrm{mmol})$ in the same solvent $(10 \mathrm{~mL})$ were added at ice-bath temperature. After $3 \mathrm{~h}$ the mixture was left to warm to room temperature and to until the dipoles were consumed $(24 \mathrm{~h})$. Under these conditions no reaction products derived from 6 with $1 \mathbf{1 a}-\mathbf{c}$ were found, but only the dimerization- and/or isomerization products of the dipoles. An analogous reaction between $\mathbf{6}$ and 1a in dimethylformamide was unsuccessful, but in contrast with the reaction in diethyl ether, it gave the abnormal dioxadiazine dimer $\mathbf{8}$ (38\% yield).

At reflux. To a solution of $6(8 \mathrm{mmol})$ in dry toluene $(10 \mathrm{~mL})$ the 1,3 -dipoles $1 \mathrm{a}-\mathbf{c}(4 \mathrm{mmol})$ in the same solvent $(10 \mathrm{~mL})$ were added portionwise and the mixture was heated at reflux for $24 \mathrm{~h}$. After removal of the solvent, the reaction mixture was subjected to column- and flash chromatography to give the mono-cycloadducts 9b,c (but not 9a), whose physical and spectroscopic data are given below.

1-Mesityl-3a,11b-dihydroisoxazolo[4,5-a]acridine (9b). Yield 12\%; mp 192-194 ${ }^{\circ} \mathrm{C}$, white crystals from ethyl acetate, (Anal. Calcd. for $\mathrm{C}_{23} \mathrm{H}_{20} \mathrm{~N}_{2} \mathrm{O}: \mathrm{C}, 81.15 ; \mathrm{H}, 5.92 ; \mathrm{N}, 8.23 \%$. Found: C, 81.25; H, 5.83; N, 8.19): ${ }^{1} \mathrm{H}-\mathrm{NMR}\left(\mathrm{CDCl}_{3}, 500 \mathrm{MHz}\right) ; \delta 1.39\left(\mathrm{~s}, 3 \mathrm{H}, \mathrm{CH}_{3}\right), 2.21\left(\mathrm{~s}, 3 \mathrm{H}, \mathrm{CH}_{3}\right)$, $2.43\left(\mathrm{~s}, 3 \mathrm{H}, \mathrm{CH}_{3}\right), 4.98$ (d, 1H, $\left.J=11.6 \mathrm{~Hz}, \mathrm{H}-11 \mathrm{~b}\right), 5.86$ (ddd, 1H, $\left.J=11.6,2.9,1.4 \mathrm{~Hz}, \mathrm{H}-3 \mathrm{a}\right)$, 6.44 (dd, 1H, J = 10.2, 2.9 Hz, H-4), 6.53 (s, 1H, mesityl H), 6.93 (s, 1H, mesityl H), 7.00 (dd, $1 \mathrm{H}, J=10.2,1.4 \mathrm{~Hz}, \mathrm{H}-5), 7.18$ (s, 1H, H-11), 7.41 (ddd, 1H, J= 5.0, 4.5, 0.9 Hz, H-9), 7.42 (d, $1 \mathrm{H}, J=5.0 \mathrm{~Hz}, \mathrm{H}-7), 7.64(\mathrm{ddd}, 1 \mathrm{H}, J=8.6,4.5,2.0 \mathrm{~Hz}, \mathrm{H}-8), 7.99$ (dd, $1 \mathrm{H}, J=8.6,0.9 \mathrm{~Hz}, \mathrm{H}-$ 10): $\delta_{\mathrm{C}}\left(\mathrm{CDCl}_{3}, 125 \mathrm{MHz}\right) ; 19.6,19.9,20.5\left(\mathrm{CH}_{3}\right), 52.1,76.7$ (C-11b and C-3a), 121.2, 124.4, $126.6,127.2,128.3,128.9,129.7,130.4,131.6,134.3,135.5,136.6,138.0,139.2,147.4$ (aromatic C), $159.2(\mathrm{C}-1)$ : MS; m/z $340\left(\mathrm{M}^{+}\right), 324(\mathrm{M}-16)^{+}, 310(\mathrm{M}-30)^{+}, 195(\mathrm{M}-145)^{+}$, $179(\mathrm{M}-161)^{+}, 161(\mathrm{M}-179)^{+}, 145(\mathrm{M}-195)^{+}$.

1-(3,5-Dichloro-2,4,6-trimethylphenyl)-3a,11b-dihydroisoxazolo[4,5-a]acridine (9c). Yield 14\%; mp 212-214 ${ }^{\circ} \mathrm{C}$, white crystals from ethyl acetate (Anal. Calcd. for $\mathrm{C}_{23} \mathrm{H}_{18} \mathrm{~N}_{2} \mathrm{O}: \mathrm{C}, 67.49 ; \mathrm{H}$, 4.43; N, 6.84\%. Found: $\mathrm{C}, 67.55 ; \mathrm{H}, 4.48 ; \mathrm{N}, 6.89.): \delta_{\mathrm{H}}\left(\mathrm{CDCl}_{3}, 200 \mathrm{MHz}\right) ; 2.21\left(\mathrm{~s}, 6 \mathrm{H}, \mathrm{CH}_{3}\right)$, 2.49 (s, 3H, $\left.\mathrm{CH}_{3}\right), 4.94$ (d, 1H, J=12.0 Hz, H-11b), 5.92 (ddd, 1H, J = 12.0, 3.0, 1.3 Hz, H-3a), 6.45 (dd, 1H, $J=10.1,3.0 \mathrm{~Hz}, \mathrm{H}-4), 7.02$ (d, 1H, $J=10.1,1.3 \mathrm{~Hz}, \mathrm{H}-5), 7.21$ (s, 1H, H-11), 7.49 (ddd, $1 \mathrm{H}, J=5.3,4.15,0.95 \mathrm{~Hz}, \mathrm{H}-9), 7.45$ (d, $1 \mathrm{H}, J=5.3 \mathrm{~Hz}, \mathrm{H}-7), 7.68$ (ddd, $1 \mathrm{H}, J=8.8$, 4.15, 2.0 Hz, H-8), 8.03 (dd, 1H, $J=8.8,0.95 \mathrm{~Hz}, \mathrm{H}-10): \delta_{\mathrm{C}}\left(\mathrm{CDCl}_{3} 50 \mathrm{MHz}\right) ; 19.2,20.4\left(\mathrm{CH}_{3}\right)$, 
52.6, 77.6 (C-11b and C-3a), 120.1, 122.6, 126.6, 124.7, 125.0, 127.6, 128.8, 130.3, 131.4, 135.3, 136.6, 137.8, 137.9, 139.1, 142.1, 144.7 (aromatic C), $159.6(\mathrm{C}-1): \mathrm{MS}: \mathrm{m} / \mathrm{z} 409\left(\mathrm{M}^{+}\right)$, $395,393(\mathrm{M}-16)^{+}, 381,379(\mathrm{M}-30)^{+}, 230(\mathrm{M}-179)^{+}, 181,179(\mathrm{M}-161)^{+}$.

Under microwave irradiation conditions. Acridine 6 (8 $\mathrm{mmol})$ and 1,3-dipoles $\mathbf{1 b}, \mathbf{c}(4 \mathrm{mmol})$ were mixed in a Pyrex vessel and irradiated at $600 \mathrm{~W}$ for $60 \mathrm{sec}$. The resulting crude mixture was subjected to flash chromatography to give oximes $\mathbf{1 0 b}, \mathbf{c}$, whose physical and spectral data are given below.

Under neat conditions. Acridine $\mathbf{6}(8 \mathrm{mmol})$ and the 1,3 -dipoles $\mathbf{1 b}, \mathbf{c}(4 \mathrm{mmol})$ were mixed in a Pyrex vessel and placed into a silicone oil bath preheated at $180{ }^{\circ} \mathrm{C}$ until the 1,3 -dipoles were consumed $(60 \mathrm{sec})$. The resulting crude mixture was subjected to flash chromatography to give oximes $\mathbf{1 0 b}, \mathbf{c}$, whose physical and spectroscopic data are given below.

1-Acridinyl-(2,4,6-trimethylphenyl)methanone oxime (10b). Yield 4\% for microwave irradiation and $9 \%$ for refluxing toluene. Physical and spectroscopic data are identical to those reported previously. ${ }^{16}$

1-Acridinyl-(3,5-dichloro-2,4,6-trimethylphenyl)methanone oxime (10c). Yield 16\% for microwave irradiation and $11 \%$ for refluxing toluene; mp $178-180{ }^{\circ} \mathrm{C}$; pale yellow crystals from methanol. (Anal. Calcd. for $\mathrm{C}_{23} \mathrm{H}_{20} \mathrm{~N}_{2} \mathrm{O}: \mathrm{C}, 81.15 ; \mathrm{H}, 5.92 ; \mathrm{N}, 8.23 \%$. Found: C, 81.21; H, 5.85; $\mathrm{N}, 8.31) ; v_{\max }(\mathrm{KBr}), 3246,1660, \mathrm{~cm}^{-1}: \delta_{\mathrm{H}}\left(\mathrm{CDCl}_{3}, 200 \mathrm{MHz}\right) ; 2.25\left(\mathrm{~s}, 3 \mathrm{H}, \mathrm{CH}_{3}\right), 2.55(\mathrm{~s}, 6 \mathrm{H}$, $\mathrm{CH}_{3}$ ), 7.52 (ddd, $1 \mathrm{H}, J=7.85,6.8,1.0 \mathrm{~Hz}, \mathrm{H}-3$ ), 7.55 (dd, $1 \mathrm{H}, J=8.1,7.5 \mathrm{~Hz}, \mathrm{H}-7$ ), 7.69 (ddd, $1 \mathrm{H}, J=8.1,7.4,1.0 \mathrm{~Hz}, \mathrm{H}-6), 8.02$ (dd, $1 \mathrm{H}, J=7.9,1.0 \mathrm{~Hz}, \mathrm{H}-8), 8.11-8.26$ (m, 2H, H-5, H-4), 8.22 (s, 1H, H-9), $8.94(\mathrm{dd}, 1 \mathrm{H}, J=7.4,1.0 \mathrm{~Hz}, \mathrm{H}-2), 11.10(\mathrm{~s}, 1 \mathrm{H}$, oxime $\mathrm{H}) ; \delta_{\mathrm{C}}\left(\mathrm{CDCl}_{3}, 50\right.$ MHz): 19.3, $20.4\left(\mathrm{CH}_{3}\right), 124.8,127.2,127.7,128.4,129.9,130.6,131.7,131.8,132.6,134.3$, $137.9,139.8,146.1,140.3,140.5,142.5,148.2$ (aromatic C), 160.8 (oxime C). MS; m/z 340 $\left(\mathrm{M}^{+}\right), 339(\mathrm{M}-1)^{+}, 323(\mathrm{M}-17)^{+}, 178(\mathrm{M}-162)^{+}$.

Conversion of $9 \mathrm{~b}, \mathrm{c}$ into oximes $10 \mathrm{~b}, \mathrm{c}$ with sodium ethoxide. To a solution of the monocycloadducts $9 \mathbf{b}, \mathbf{c}(0.1 \mathrm{mmol})$ in anhydrous ethanol $(20 \mathrm{~mL})$ was added a solution of $0.1 \mathrm{M}$ sodium ethoxide in ethanol $(10 \mathrm{~mL})$ and the resulting mixture was refluxed until the starting material disappeared (ca. $30 \mathrm{~min}$ ). After removal of the solvent under reduced pressure, the residue was taken up with water $(10 \mathrm{~mL})$, extracted three times with ethyl acetate $(10 \mathrm{~mL})$, dried over sodium sulfate and concentrated under reduced pressure to give the oximes $\mathbf{1 0 b}, \mathbf{c}$, which were purified by chromatography and crystallized from ethyl acetate $(91 \%$ and $93 \%$ yield, respectively). Their physical and spectroscopic data were identical to those of authentic samples.

Conversion of $9 \mathrm{~b}, \mathrm{c}$ into oximes $10 \mathrm{~b}, \mathrm{c}$ with $\mathrm{LiAlH}_{4}$. To a stirred solution of $\mathbf{9 b}, \mathbf{c}(0.1 \mathrm{mmol})$ in dried THF $(10 \mathrm{~mL}), \mathrm{LiAlH}_{4}(3 \mathrm{mmol})$ was added at $0^{\circ} \mathrm{C}$ and the mixture allowed to react under stirring until the starting material disappeared (5h). After hydrolysis, the reaction mixture was diluted with dichloromethane and the organic layer washed with water $(2 \times 10 \mathrm{~mL})$, dried over sodium sulfate and concentrated under reduced pressure to give, after purification by chromatography and crystallization (ethyl acetate), the oximes $\mathbf{1 0 b}, \mathbf{c}(85 \%$ and $87 \%$ yield, 
respectively), whose physical and spectroscopic data were identical to those of authentic samples.

Conversion of $9 \mathrm{~b}$ into oxime $10 \mathrm{~b}$ by heating without solvent. The mono-cycloadduct $9 \mathrm{~b}$ $(0.1 \mathrm{mmol})$ in a Pyrex vessel and then plunged into a silicone oil bath, preheated at $180^{\circ} \mathrm{C}$, for 60 sec. The ${ }^{1} \mathrm{H}-\mathrm{NMR}$ of the resulting crude mixture showed only the signals characteristic of oxime $10 b$.

Hydrogenation of $9 \mathrm{~b}$ with $\mathbf{P d} / \mathbf{C}$. A suspension of $9 \mathrm{~b}(0.1 \mathrm{mmol})$ in methanol $(10 \mathrm{~mL})$ and a spatula-tip (ca. $20 \mathrm{mg}$ ) of $\mathrm{Pd} / \mathrm{C}(10 \%)$ were placed in a hydrogenation vessel, and shaken mechanically for $6 \mathrm{~h}$ under hydrogen (60 psi). The reaction mixture was then filtered through Celite $^{\circledR}$ and the resulting solution concentrated under reduced pressure to yield the tetrahydroisoxazole 11, whose physical and spectral data are given below.

1-Mesityl-3a,4,5,11b-tetrahydroisoxazolo-[4,5-a]acridine (11). Yield 80\%; mp 172-174 ${ }^{\circ} \mathrm{C}$, pale yellow crystals from ethyl acetate (Anal. Calcd. for $\mathrm{C}_{33} \mathrm{H}_{22} \mathrm{~N}_{2} \mathrm{O}: \mathrm{C}, 80.67 ; \mathrm{H}, 6.48 ; \mathrm{N}$, 8.18\%. Found: $\mathrm{C}, 80.75 ; \mathrm{H}, 6.51 ; \mathrm{N}, 8.23): \delta_{\mathrm{H}}\left(\mathrm{CDCl}_{3}, 500 \mathrm{MHz}\right) ; 1.22\left(\mathrm{~s}, 3 \mathrm{H}, \mathrm{CH}_{3}\right), 1.68(\mathrm{~m}$, 2H, H-5, H-5'), 2.00 (m, 1H, H-4), 2.25 (s, 3H, $\mathrm{CH}_{3}$ ), 2.45 (s, 3H, CH 3 ), 2.64 (m, 1H, H-4'), 6.58 (s, 1H, mesityl H), 6.96 (s, 1H, mesityl H), 7.28 (m, 1H, H-8), 7.47 (m, 2H, H-10, H-11), $7.72(\mathrm{~m}, 1 \mathrm{H}, \mathrm{H}-9), 8.18(\mathrm{~m}, 1 \mathrm{H}, \mathrm{H}-7): \delta_{\mathrm{C}}\left(\mathrm{CDCl}_{3}, 125 \mathrm{MHz}\right) 19.9,20.5,21.1\left(\mathrm{CH}_{3}\right), 22.5,26.9$, (C-4 and C-5), 53.9, 77.0 (C-11b and C-3a), 123.1, 123.8, 124.0, 125.6, 127.4, 127.6, 129.8, 131.6, 138.2, 139.5, 141.1, 151.8 (aromatic C), 158.7 (C-1): MS; m/z $342\left(\mathrm{M}^{+}\right), 326(\mathrm{M}-16)^{+}$, $312(\mathrm{M}-30)^{+}, 147(\mathrm{M}-195)^{+}, 195(\mathrm{M}-147)^{+}, 181(\mathrm{M}-161)^{+}, 161(\mathrm{M}-184)^{+}$.

Hydrogenation of 9b with Raney nickel. A suspension of $9 \mathrm{~b}$ (2.0 mmol) and a spatula-tip (ca. $200 \mathrm{mg}$ ) of Raney Nickel in ethanol $(10 \mathrm{~mL})$ were placed in a hydrogenation vessel, and shaken mechanically for $4 \mathrm{~h}$ under hydrogen (30 psi). The reaction mixture was then filtered through Celite $^{\circledR}$ and then concentrated under reduced pressure. The ${ }^{1} \mathrm{H}-\mathrm{NMR}$ of the reaction mixture showed numerous products and was not separated.

Cycloaddition reactions of 1 with $2 \mathrm{~b}$ in 1:10 ratio. To a solution of 6 (4 mmol) in refluxing dry toluene $(10 \mathrm{~mL}), \mathbf{1 b}(40 \mathrm{mmol})$ was added portionwise in the same solvent $(30 \mathrm{~mL})$. The mixture was heated at reflux until the dipole was consumed (3 days). After removing the solvent, the reaction mixture was subjected to flash chromatography to give the mono-cycloadduct $9 \mathbf{b}$ $(25 \%)$, the oxime $\mathbf{1 0 b}(3 \%)$, and two new cycloadducts 12 and 13, whose physical and spectral data are given below.

3,6-Dimesityl-3a,12b-dihydroisoxazolo[5,4-a:5',4'-c]acridine (12). Yield 8\%; mp 180-182 ${ }^{\circ} \mathrm{C}$, white crystals from ethyl acetate (Anal. Calcd. for $\mathrm{C}_{33} \mathrm{H}_{29} \mathrm{~N}_{3} \mathrm{O}_{2}: \mathrm{C}, 79.33 ; \mathrm{H}, 5.85 ; \mathrm{N}, 8.41 \%$. Found: C, 79.44; H, 5.71; N, 8.47): $\delta_{\mathrm{H}}\left(\mathrm{CDCl}_{3}, 500 \mathrm{MHz}\right) ; 2.08\left(\mathrm{~s}, 6 \mathrm{H}, \mathrm{CH}_{3}\right), 2.18\left(\mathrm{~s}, 6 \mathrm{H}, \mathrm{CH}_{3}\right)$, $2.32\left(\mathrm{~s}, 3 \mathrm{H}, \mathrm{CH}_{3}\right), 2.40\left(\mathrm{~s}, 3 \mathrm{H}, \mathrm{CH}_{3}\right), 5.19$ (d, 1H, J = $\left.10 \mathrm{~Hz}, \mathrm{H}-3 \mathrm{a}\right), 6.29$ (d, 1H, J = $10 \mathrm{~Hz}, \mathrm{H}-$ 12b), 6.95 (s, 2H, mesityl H), 6.97 (s, 2H, mesityl H), 7.47 (m, 1H, H-9), 7.59 (m, 2H, H-5, H-8), 7.79 (d, 1H, $J=8.0, \mathrm{~Hz}, \mathrm{H}-10), 8.34$ (s, 1H, H-11): $\delta_{\mathrm{C}}\left(\mathrm{CDCl}_{3}, 125 \mathrm{MHz}\right) ; 19.6,20.1,20.2,21.2$ $\left(\mathrm{CH}_{3}\right), 48.9,81.4$ (C-12b and C-3a), 114.8 (isoxazole C-6a), 123.2, 123.6, 125.0, 126.5, 127.6, $127.7,127.9,128.8,129.6,130.1,137.0,137.4,137.4,138.5,139.6,146.2$ (aromatic C), 148.1 
(C-3b), 158.5 (C-3), 164.4 (C-6): MS; m/z $499\left(\mathrm{M}^{+}\right), 483(\mathrm{M}-16)^{+}, 357(\mathrm{M}-145)^{+}, 338(\mathrm{M}-$ $161)^{+}, 321(\mathrm{M}-178)^{+}, 308(\mathrm{M}-191)^{+}, 178(\mathrm{M}-321)^{+}$.

5-Acridin-1-yl-3,5-dimesityl-1,2,4-oxadiazol-(5H)-ol (13). Yield 7\%; mp 139-141 ${ }^{\circ} \mathrm{C}$, pale yellow crystals from ethyl acetate (Anal. Calcd. for $\mathrm{C}_{33} \mathrm{H}_{31} \mathrm{~N}_{3} \mathrm{O}_{2}: \mathrm{C}, 79.01 ; \mathrm{H}, 6.23 ; \mathrm{N}, 8.38 \%$. Found: C, 79.27; H, 6.18; N, 8.47); $v_{\max }(\mathrm{KBr}) 3352,1640 \mathrm{~cm}^{-1}: \delta_{\mathrm{H}}\left(\mathrm{CDCl}_{3}, 500 \mathrm{MHz}\right) ; 2.26(\mathrm{~s}$, $\left.9 \mathrm{H}, \mathrm{CH}_{3}\right), 2.29\left(\mathrm{~s}, 3 \mathrm{H}, \mathrm{CH}_{3}\right), 2.44\left(\mathrm{~s}, 6 \mathrm{H}, \mathrm{CH}_{3}\right), 6.88(\mathrm{~s}, 2 \mathrm{H}$, mesityl H), 6.92 (br s, 1H, OH or $\mathrm{NH}$; exchangeable with $\left.\mathrm{D}_{2} \mathrm{O}\right), 6.93(\mathrm{~s}, 2 \mathrm{H}$, mesityl H), $7.52(\mathrm{~m}, 2 \mathrm{H}, \mathrm{H}-3, \mathrm{H}-7), 7.72(\mathrm{~m}, 1 \mathrm{H}, \mathrm{H}-$ 2), 7.82 (m, 1H, H-8), 7.97 (dd, 1H, $J=8.8,3.6 \mathrm{~Hz}, \mathrm{H}-4), 8.05$ (m, 2H, H-1, H-9), 8.74 (s, 1H, $\mathrm{H}-5): \delta_{\mathrm{C}}\left(\mathrm{CDCl}_{3}, 125 \mathrm{MHz}\right) ; 18.9,20.9\left(\mathrm{CH}_{3}\right), 115.2$ (C-5), 160.7 (C-3), 125.9, 126.3, 126.4, $127.9,128.9,129.8,130.1,130.7,131.9,135.9,136.9,137.8,138.8,145.3,148.8$ (aromatic C): MS; m/z $501\left(\mathrm{M}^{+}\right), 340(\mathrm{M}-161)^{+}, 322(\mathrm{M}-179)^{+}, 309(\mathrm{M}-192)^{+}, 205(\mathrm{M}-296)^{+}, 179(\mathrm{M}-$ $322)^{+}, 161(\mathrm{M}-340)^{+}$.

\section{Acknowledgments}

The authors thank the Italian M.U.R.S.T. for financial support.

\section{References}

1. Corsaro, A.; Perrini, G.; Caramella, P.; Marinone Albini, F.; Bandiera, T. Tetrahedron Lett. 1986, 1517.

2. Ross, J. A.; Seiders, R. P.; Lemal D. M. J. Am. Chem. Soc. 1976, 98, 4325.

3. Marinone Albini, F.; De Franco, R.; Bandiera, T.; Caramella, P.; Corsaro, A.; Perrini, G. J. Heterocyclic Chem. 1989, 26, 757.

4. Caramella, P.; Bandiera, T.; Marinone Albini, F.; Gamba, A.; Corsaro, A.; Perrini, G. Tetrahedron 1988, 44, 4917.

5. Corsaro, A.; Perrini, G.; Pistarà, V.; Quadrelli, P.; Gamba Invernizzi, A.; Caramella, P. Tetrahedron 1996, 52, 6421.

6. Selby, I. A. In Acridines: The Chemistry of Heterocyclic Compounds; Acheson, R. M., Ed.; Interscience: London, 1973; Vol. 9, Ch. 5; pp 434-437.

7. Foucart, J.; Nasielski, J.; Vander Donckt, E. Bull. Soc. Chim. Belges 1966, 75, 17.

8. Raulins, N. R. In Acridines: The Chemistry of Heterocyclic Compounds; Acheson, R. M., Ed.; Interscience: London; 1973; Vol. 9, Ch. 1, pp 63-67.

9. Corsaro, A.; Librando, V.; Chiacchio, U.; Pistarà, V. Tetrahedron 1996, 52, 13027.

10. Librando, V.; Chiacchio, U.; Corsaro, A.; Gumina, G. Polycyclic Aromatic Compounds 1996, $11,313$.

11. Corsaro, A.; Chiacchio, U.; Librando, V.; Fisichella, S.; Pistarà, V. Heterocycles 1997, 45, 1567. 
12. Corsaro, A.; Librando, V.; Chiacchio, U.; Pistarà, V.; Rescifina A. Tetrahedron 1998, 54, 9187.

13. Fukui, K.; Yonezawa, T.; Nagata, C.; Shingu, H. J. Chem. Phys. 1954, 22, 1433.

14. Quilico, A.; Speroni, G. Gazz. Chim. Ital. 1946, 76, 146.

15. De Sarlo, F.; Guarna, A. J. Chem. Soc., Perkin Trans. 2 1976, 626.

16. Grünanger P.; Vita-Finzi, P. In Isoxazoles: The Chemistry of Heterocyclic Compounds, Grünanger P.; Vita-Finzi, P., Eds; John Wiley \& Sons Inc.: New York, 1991; Vol. 49, Part I; pp 517-571.

17. Corsaro, A.; Chiacchio, U.; Librando, Pistarà, V.; Rescifina, A. Synthesis 2000, 1469.

18. (a) Bast, K.; Christl, M.; Huisgen, R.; Mack, W. Chem. Ber. 1972, 105, 2825. (b) Harada, K.; Kaji, E.; Zen, S. Chem. Pharm. Bull. 1980, 28, 3296. (c) Aurich, H. G.; Stork, K. Chem. Ber. 1975, 108, 2764. (d) Morrocchi, S.; Ricca, A. Chim. Ind. (Milan) 1967, 49, 629. (e) Fetizon, M.; Golfier, M.; Milcent, R.; Papadakis, I. Tetrahedron 1975, 31, 165.

19. Corsaro, A.; Chiacchio, U.; Perrini, G.; Pistarà, V.; Purrello, G.; Scarlata, G. J. Chem. Res. (S) 1995, 352; (M), 2015.

20. Caramella P.; Grünanger, P. In 1,3-Dipolar Cycloaddition Chemistry, Padwa, A., Ed.; Wiley: Interscience, New York, 1984; Vol. 1, Ch. 3; pp 291-392.

21. Bianchetti, G.; Pocar, D.; Dalla Croce, P. Gazz. Chim. Ital. 1963, 93, 1714.

22. Beltrame, P.; Veglio, C.; Simonetta, M. J. Chem. Soc. (B) 1967, 867.

23. Grundmann, C.; Dean, G. M. J. Org. Chem. 1965, 30, 2809.

24. Perrin, D. D.; Armarego, W. L. F.; Perrin, D. F. In Purification of Laboratory Chemicals, $2^{\text {nd }}$ Edn; Pergamon: New York, 1980. 